\title{
Short Communication: Serum and Tissue Concentrations of Vitamin D Metabolites in Beef Heifers After Buccal Dosing of 25-Hydroxyvitamin $D_{3}$
}

\author{
J. D. Rivera, ${ }^{1}$ S. E. Bachman, ${ }^{2}$ M. E. Hubbert, ${ }^{2}$ M. E. Branine,${ }^{3}$ R. L. Horst,${ }^{4}$ \\ S. N. Williams, ${ }^{5}$ and M. L. Galyean ${ }^{1}$ \\ ${ }_{1}^{1}$ Department of Animal and Food Sciences, Box 42141, Texas Tech University, Lubbock 79409-2141 \\ ${ }^{2}$ Ganado Research, LLC, Amarillo, TX 79109 \\ ${ }^{3}$ Cactus Research, Ltd., Cactus, TX 79013 \\ ${ }^{4}$ USDA-ARS National Animal Disease Center, Ames, IA 50010-0070 \\ ${ }^{5}$ DSM Nutritional Products, Inc., Parsippany, NJ 07054-1298
}

\begin{abstract}
Sixteen crossbred (British $\times$ Continental; average unshrunk body weight $=507.9 \mathrm{~kg} ; \mathrm{SD}=45.6 \mathrm{~kg}$ ) beef heifers fed a steam-flaked corn-based finishing diet with melengestrol acetate $(0.4 \mathrm{mg} /$ heifer daily) included to suppress estrus were used in a completely random design to evaluate the efficacy of buccal administration of $0,10,100$, or $1000 \mathrm{mg}$ of 25-hydroxyvitamin $\mathrm{D}_{3}$, (25$\mathrm{OH} \mathrm{D}_{3}$ ). Serum $\mathrm{Ca}, \mathrm{P}, \mathrm{Mg}, 25-\mathrm{OH} \mathrm{D}_{3}, 1$,25-dihydroxyvitamin $\mathrm{D}\left[1,25-(\mathrm{OH})_{2} \mathrm{D}_{3}\right]$, albumin, and protein were measured $24 \mathrm{~h}$ before dosing $(-24 \mathrm{~h})$, at dosing $(0 \mathrm{~h})$, and 6 and $24 \mathrm{~h}$ after dosing, after which the cattle were slaughtered at a commercial facility. Samples of kidneys, liver, longissimus lumborum, and triceps brachii were collected and evaluated for concentrations of $1,25-(\mathrm{OH})_{2} \mathrm{D}_{3}$. With -24 and $0 \mathrm{~h}$ as baseline covariates, a significant time $\times$ treatment interaction was observed for serum 25- $\mathrm{OH} \mathrm{D}_{3}$ and Ca concentrations, but not for serum 1,25- $(\mathrm{OH})_{2} \mathrm{D}_{3}$. Supplemental 25-OH $\mathrm{D}_{3}$ doses of 100 and $1000 \mathrm{mg}$ significantly increased serum $25-\mathrm{OH} \mathrm{D}_{3}$ at $24 \mathrm{~h}$ after dosing, $1,25-(\mathrm{OH})_{2} \mathrm{D}_{3}$ at 6 and $24 \mathrm{~h}$ after dosing, and serum $\mathrm{Ca}$ at $24 \mathrm{~h}$ after dosing. Similarly, buccal dosing of $1000 \mathrm{mg}$ of supplemental 25- $\mathrm{OH} \quad \mathrm{D}_{3}$ significantly increased (approximately 2 - to 3 -fold) concentrations of $1,25-(\mathrm{OH})_{2} \mathrm{D}_{3}$ in the kidney, liver, and longissimus lumborum relative to the other 3 treatments but not in triceps brachii. Serum albumin, protein, $\mathrm{P}$, and $\mathrm{Mg}$ were not affected by treatment. Based on these results, buccal administration of 100 and $1000 \mathrm{mg} 25-\mathrm{OH} \mathrm{D}_{3}$ increased vitamin $\mathrm{D}_{3}$ metabolites in serum and tissues, and it should be an effective method of delivering the vitamin.
\end{abstract}

(Key words: beef cattle, calcium, vitamin D)

Received November 9, 2004.

Accepted December 21, 2004.

Corresponding author: M. L. Galyean; e-mail: michael.galyean@ ttu.edu.
Abbreviation key: 25-OH $\mathbf{D}_{3}=25$-hydroxyvitamin $\left.\mathrm{D}_{3}, \mathbf{1 , 2 5}-\mathbf{( O H}\right)_{\mathbf{2}} \mathbf{D}_{\mathbf{3}}=1,25$-dihydroxy vitamin $\mathrm{D}_{3}, \mathbf{P G}=$ propylene glycol.

Dietary vitamin $\mathrm{D}$ is absorbed in the small intestine and hydroxylated in the liver to form 25-hydroxyvitamin $\mathrm{D}_{3}\left(\mathbf{2 5}-\mathbf{O H} \mathbf{D}_{3}\right)$, the major circulating form of the vitamin (Reinhart and Hustmyer, 1987), which is further hydroxylated in the kidney to form 1,25-dihydroxy vitamin $\mathrm{D}_{3}\left(\mathbf{1 , 2 5}-(\mathbf{O H})_{2} \mathbf{D}_{3}\right)$, the active form of the vitamin (Reinhart and Hustmyer, 1987.) The active form functions in $\mathrm{Ca}$ and $\mathrm{P}$ homeostasis (Hodnett et al., 1992) through mediation of parathyroid hormone (NRC, 1987), immune system regulation (Reinhart and Hustmyer, 1987), and regulation of fluid balance by its effect on rennin and angiotensin II (Li, 2003). Effects of supplemental vitamin $\mathrm{D}$ and various metabolites on parturient paresis in dairy cattle have been studied extensively (e.g., Hove et al., 1983; Hodnett et al., 1992.) Moreover, feeding high doses of vitamin D may improve tenderness of beef (Karges et al., 2001; Montgomery et al., 2000, 2004b). Typically, vitamin D is supplemented in the diet or injected; however, variations in DMI may lead to less than optimal doses of the vitamin being consumed, and concerns regarding injection site lesions (Roeber et al., 2002) warrant examination of alternative delivery methods. Rivera et al. (2003) reported that oral drenching of vitamin $\mathrm{E}$ was as effective for administering the vitamin as subcutaneous injection for newly received, stressed beef cattle. Transmucosal delivery by the buccal route is an effective means of delivering various human medications (Cefalu, 2002; Belmin and Valensi, 2003.) Moreover, Okura et al. (2004) recently demonstrated effective absorption of $1,25-(\mathrm{OH})_{2} \quad \mathrm{D}_{3}$ after vaginal administration in Holstein heifers. Therefore, the objective of this experiment was to evaluate the efficacy of buccal administration of $25-\mathrm{OH} \mathrm{D}_{3}$ in beef cattle. 25-Hydroxyvitamin $\mathrm{D}$ was chosen as the vitamin $\mathrm{D}$ source in this experiment because we hypothesized that buccal delivery of an active component of 
the vitamin $\mathrm{D}$ cascade would decrease the time required to increase blood concentrations of the active metabolite, $1,25-(\mathrm{OH})_{2} \mathrm{D}_{3}$.

All procedures involving animals were done in accordance with recommendations detailed in the Guide for Care and Use of Agricultural Animal in Agricultural Research and Teaching (FASS, 1999).

Sixteen British $\times$ Continental beef heifers were selected randomly from a pen of cattle at a commercial feedlot in Hereford, TX. The cattle had been on feed for approximately $120 \mathrm{~d}$, and were scheduled to ship to slaughter in a few days. The live, unshrunk BW of the heifers was measured 4 times over the experimental period, and it averaged $507.9 \mathrm{~kg}(\mathrm{SD}=45.6 \mathrm{~kg})$. The diet fed to the cattle was a typical finishing diet that consisted primarily of steam-flaked corn, animal fat, corn silage, alfalfa hay, and a protein/mineral supplement. The diet included melengestrol acetate (MGA; Pfizer Animal Health, Lees Summit, MO; 0.4 mg/heifer daily) to suppress estrus, and it supplied Rumensin and Tylan (Elanco Animal Health, Indianapolis, IN) at manufacturer's suggested concentrations (approximately 27.5 to $33 \mathrm{mg} / \mathrm{kg}$ and 8.8 to $11 \mathrm{mg} / \mathrm{kg}$, respectively), with $\mathrm{CP}$ and NEg concentrations (DM basis) of approximately $13.5 \%$ and $1.52 \mathrm{Mcal} / \mathrm{kg}$, respectively. The heifers were assigned randomly to 1 of 4 treatments: 1) $1 \mathrm{~mL}$ of a propylene glycol (PG) solution (0); 2) $1 \mathrm{~mL}$ of a PG solution that contained $10 \mathrm{mg}$ of 25 $\mathrm{OH} \mathrm{D}_{3}(10)$; 3) $1 \mathrm{~mL}$ of a $\mathrm{PG}$ solution that contained $100 \mathrm{mg}$ of $25-\mathrm{OH} \mathrm{D}_{3}(100)$; or 4) $10 \mathrm{~mL}$ of a PG solution that contained $100 \mathrm{mg}$ of $25-\mathrm{OH} \mathrm{D} \mathrm{D}_{3} / \mathrm{mL}$ (1000). Treatments were administered by restraining the animal in a squeeze chute and discharging the appropriate dose for each of the 4 treatments into the side of the mouth (cheek area; a 3-mL syringe was used for the 0, 10-, and 100-mg treatments, and a $10-\mathrm{mL}$ syringe was used for the 1000-mg treatment). Following administration of 25-OH $\mathrm{D}_{3}$, the heifers were group-housed in a soilsurfaced pen, with ad libitum access to feed and water. The heifers were observed at $0,1,2,6$, and $12 \mathrm{~h}$ for adverse effects. Blood was collected via jugular venipuncture using vacuum tubes $24 \mathrm{~h}$ before dosing ( -24 $\mathrm{h}$ ), at dosing $(0 \mathrm{~h})$, and at 6 and $24 \mathrm{~h}$ after dosing. Blood samples were allowed to clot and then centrifuged at approximately $1000 \times g$ for $15 \mathrm{~min}$, after which serum was decanted and stored frozen for subsequent analysis of $\mathrm{Ca}, \mathrm{P}, \mathrm{Mg}$, albumin, protein, $25-\mathrm{OH} \mathrm{D}_{3}$, and 1,25$(\mathrm{OH})_{2} \mathrm{D}_{3}$. Following the last sample collection, the cattle were shipped approximately $10 \mathrm{~km}$ to a commercial slaughter facility. Both kidneys, along with the liver, lungs, heart, adrenal glands, and parathyroid tissues were obtained at slaughter. Following a 48-h chill, tissue samples from the longissimus lumborum and triceps brachii were collected. Carcasses of the heifers dosed with $1000 \mathrm{mg}$ of $25-\mathrm{OH} \mathrm{D}_{3}$ were rendered and not used for human consumption. Serum samples were analyzed for $25-\mathrm{OH} \mathrm{D}_{3}$ and $1,25-(\mathrm{OH})_{2} \mathrm{D}_{3}$ at the Diagnostic Center for Population and Animal Health, Michigan State Univ., East Lansing, MI, using commercially available kits $\left(25-\mathrm{OH} \mathrm{D}{ }_{3},{ }^{125} \mathrm{I}\right.$ Kit, catalog no. $68100 \mathrm{E}$; and 1,25- $(\mathrm{OH})_{2} \mathrm{D}_{3},{ }^{125} \mathrm{I}$ Kit, catalog no. $65100 \mathrm{E}$; DiaSorin, Inc., Stillwater, MN). Extraction of samples and performance of the vitamin D metabolite assays were done in accordance with the manufacturer's protocols. When 3 different quantities of $25-\mathrm{OH} \mathrm{D}_{3}$ were added to each of 5 serum samples before extraction, an average of $103 \%$ was recovered in the assay. In serum pools with concentrations of $25-\mathrm{OH} \mathrm{D}$ of 61 and $161 \mathrm{nmol} /$ $\mathrm{L}$, the respective intraassay CV were 9.1 and $8.7 \%$, and interassay CV were 13 and 13\% (10 assays), respectively. When 3 different quantities of $1,25-(\mathrm{OH})_{2} \quad \mathrm{D}_{3}$ were added to each of 5 serum pools, an average of $94 \%$ was measured in the assay. In control sera, with concentrations of $1,25-(\mathrm{OH})_{2} \mathrm{D}_{3}$ of 50 and $155 \mathrm{pmol} / \mathrm{L}$, the respective intraassay CV were 9.9 and $5.5 \%$, and interassay CV were 19.9 and 23.6\% (13 assays). Concentrations of $1,25-\mathrm{OH}_{2} \mathrm{D}_{3}$ in liver, kidneys, longissimus lumborum, and triceps brachii were analyzed at the Periparturient Diseases of Cattle Research Unit, National Animal Disease Center, Ames, IA, according to procedures described by Montgomery et al. (2000). Serum $\mathrm{Ca}, \mathrm{P}, \mathrm{Mg}$, albumin, protein (spectrophotometric procedures), and histopathology on liver, lung, kidney, heart, adrenal, and parathyroid were analyzed at the Texas Veterinary Diagnostic Laboratory in Amarillo, TX. This laboratory is accredited by the American Association of Veterinary Laboratory Diagnosticians.

Serum constituents were analyzed as a completely random design repeated over time (6 and $24 \mathrm{~h}$ after dosing) with PROC MIXED (SAS Inst., Inc., Cary, NC). Serum data collected at -24 and $0 \mathrm{~h}$ were included in the model as baseline covariates. Preplanned comparisons ( 0 vs. 10 ; 0 vs. 100 ; and 0,10 , and 100 vs. 1000 ) were conducted using contrast statements in PROC MIXED. When a time $\times$ treatment interaction was detected $(P$ $<0.05$ ), preplanned comparisons were evaluated within time period; otherwise, contrasts of means averaged over time were evaluated. Tissue concentrations were analyzed as a completely random design using PROC GLM, with the same preplanned contrasts used for serum data.

No symptoms of toxicity were evident in the cattle. Similarly, no soft tissue ossification was noted at the time of slaughter, and histopathology on liver, lung, kidney, heart, adrenal, and parathyroid indicated no gross abnormalities (data not shown).

Data for serum 25-OH $\mathrm{D}_{3}$ and $1,25-(\mathrm{OH})_{2} \mathrm{D}_{3}$ concentrations are presented in Tables 1 and 2, respectively. 
Table 1. Effect of buccal administration of 25-hydroxyvitamin $\mathrm{D}_{3}\left(25-\mathrm{OH} \mathrm{D}_{3}\right)$ on serum $25-\mathrm{OH} \mathrm{D}_{3}(\mathrm{ng} / \mathrm{mL})$ in finishing beef heifers. ${ }^{1}$

\begin{tabular}{|c|c|c|c|c|c|c|c|c|}
\hline \multirow[b]{2}{*}{ Time,${ }^{3} \mathrm{~h}$} & \multicolumn{4}{|c|}{$25-\mathrm{OH} \mathrm{D} \mathrm{D}_{3}$ dose, $\mathrm{mg}$} & \multirow[b]{2}{*}{$\mathrm{SEM}^{4}$} & \multicolumn{3}{|c|}{$\mathrm{OSL}^{2}$} \\
\hline & 0 & 10 & 100 & 1000 & & 0 vs. 10 & 0 vs. 100 & Others vs. 1000 \\
\hline-24 & 35.2 & 26.1 & 32.4 & 18.4 & 7.80 & 0.43 & 0.80 & 0.18 \\
\hline 0 & 45.4 & 29.7 & 42.8 & 30.8 & 6.25 & 0.10 & 0.77 & 0.26 \\
\hline 6 & 44.3 & 48.2 & 72.1 & 395.7 & - & 0.86 & 0.20 & 0.001 \\
\hline 24 & 50.4 & 72.9 & 153.9 & 404.5 & - & 0.34 & 0.001 & 0.001 \\
\hline
\end{tabular}

${ }^{1} \mathrm{n}=4$ per time and treatment combination.

${ }^{2} \mathrm{OSL}=$ Observed significance level for the preplanned contrasts.

${ }^{3}$ Time relative to administration of $25-\mathrm{OH} \mathrm{D}_{3}$. Times -24 and $0 \mathrm{~h}$ were used as baseline covariates in the repeated measures analysis of 6 - and 24 -h data. Sampling time $\times$ treatment interaction $(P<0.001)$ for samples collected at 6 and $24 \mathrm{~h}$.

${ }^{4}$ Pooled standard error of the treatment means for -24 - and 0 -h samples. Covariance-adjusted pooled standard errors for samples collected at 6 and $24 \mathrm{~h}$ were $15.2,15.2,14.8$, and $15.1 \mathrm{ng} / \mathrm{mL}$ for the $0,10,100$, and $1000 \mathrm{mg}$ treatments, respectively.

A time $\times$ treatment interaction $(P<0.001)$ was observed for serum $25-\mathrm{OH} \mathrm{D}_{3}$ data, but not for serum $1,25-(\mathrm{OH})_{2}$ $\mathrm{D}_{3}$ data $(P \geq 0.33)$; however, for consistency of presentation, means within each time period are reported for both variables. The $100-\mathrm{mg}$ dose of $25-\mathrm{OH} \mathrm{D} \mathrm{D}_{3}$ increased $(P=0.001)$ serum $25-\mathrm{OH} \mathrm{D}_{3}$ at $24 \mathrm{~h}$ after dosing, whereas the $1000-\mathrm{mg}$ dose increased $(P=0.001)$ serum $25-\mathrm{OH} \mathrm{D}_{3}$ at both 6 and $24 \mathrm{~h}$ after dosing compared with the other treatments, with the peak at $404.5 \mathrm{ng} /$ $\mathrm{mL}$ at $24 \mathrm{~h}$. No differences $(P \geq 0.34)$ were noted between cattle receiving the 0 and $10 \mathrm{mg}$ treatments for serum 25 - $\mathrm{OH} \mathrm{D}_{3}$ concentrations at either time after dosing. Littledike and Horst (1982) reported an increase in plasma $25-\mathrm{OH} \mathrm{D}_{3}$ when cattle were administered $15 \times$ $10^{6} \mathrm{IU}$ of vitamin $\mathrm{D}_{3}$ on $\mathrm{d} 0$ followed by a second injection of a lesser concentration $7 \mathrm{~d}$ later.

As expected with the increase in $25-\mathrm{OH} \mathrm{D}_{3}$ in the present study, serum $1,25-(\mathrm{OH})_{2} \mathrm{D}_{3}$ increased $(P=$ 0.001 to 0.006 ) at 6 and $24 \mathrm{~h}$ after dosing for both the 100 and 1000 doses, with a peak at $165.7 \mathrm{pg} / \mathrm{mL} 24 \mathrm{~h}$ after dosing when cattle were administered $1000 \mathrm{mg}$ of $25-\mathrm{OH} \mathrm{D} \mathrm{D}_{3}$ (Table 2). In contrast to results with serum concentrations of $25-\mathrm{OH} \mathrm{D}_{3}$, the $10-\mathrm{mg}$ dose tended $(P=$ $0.06)$ to increase serum $1,25-(\mathrm{OH})_{2} \mathrm{D}_{3}$ at $24 \mathrm{~h}$ after dosing compared with control. 25-Hydroxyvitamin $\mathrm{D}_{3}$ is metabolized by the kidney to $1,25-(\mathrm{OH})_{2} \mathrm{D}_{3}$, which is the form required for $\mathrm{Ca}$ absorption (NRC, 1987). Previous research has shown that both feeding and injecting 25-OH $\mathrm{D}_{3}$ and 1,25- $(\mathrm{OH})_{2} \mathrm{D}_{3}$ increase serum and plasma concentrations of these metabolites. Hove et al. (1983) reported peak plasma $1,25-(\mathrm{OH})_{2} \mathrm{D}_{3}$ at 200 $\mathrm{pg} / \mathrm{mL}$ when cattle were fed $500 \mu \mathrm{g}$ of $1,25-(\mathrm{OH})_{2} \mathrm{D}_{3}$ in a pelleted form mixed into a daily ration, whereas an i.m. injection of $1,25-(\mathrm{OH})_{2} \mathrm{D}_{3}$ resulted in a peak concentration of approximately $1000 \mathrm{pg} / \mathrm{mL}$ within $12 \mathrm{~h}$. Likewise, when Hodnett et al. (1992) injected $0.5 \mathrm{mg}$ of 1$\alpha(\mathrm{OH})_{2} \mathrm{D}_{3}$ and $4 \mathrm{mg}$ of $25-\mathrm{OH} \mathrm{D}_{3}$ into dairy cattle, serum $1,25-(\mathrm{OH})_{2} \mathrm{D}_{3}$ peaked at $125 \mathrm{pg} / \mathrm{mL}$.

These data demonstrate that buccal administration is an effective route to rapidly increase serum concen-

Table 2. Effects of buccal administration of 25-hydroxyvitamin $\mathrm{D}_{3}\left(25-\mathrm{OH} \mathrm{D}_{3}\right)$ on serum 1,25-dihydroxy vitamin $\mathrm{D}_{3}(\mathrm{pg} / \mathrm{mL})$ in finishing beef heifers.

\begin{tabular}{|c|c|c|c|c|c|c|c|c|}
\hline \multirow[b]{2}{*}{ Time,$^{3} \mathrm{~h}$} & \multicolumn{4}{|c|}{$25-\mathrm{OH} \mathrm{D}_{3}$ dose, $\mathrm{mg}$} & \multirow[b]{2}{*}{$\mathrm{SEM}^{4}$} & \multicolumn{3}{|c|}{$\mathrm{OSL}^{2}$} \\
\hline & 0 & 10 & 100 & 1000 & & 0 vs. 10 & 0 vs. 100 & Others vs. 1000 \\
\hline-24 & 33.3 & 49.8 & 33.7 & 50.6 & 8.83 & 0.21 & 0.98 & 0.27 \\
\hline 0 & 29.5 & 38.1 & 62.9 & 52.3 & 15.42 & 0.70 & 0.15 & 0.63 \\
\hline 6 & 19.1 & 35.6 & 147.5 & 132.0 & - & 0.47 & 0.001 & 0.004 \\
\hline 24 & 55.8 & 102.8 & 157.7 & 165.7 & - & 0.06 & 0.001 & 0.006 \\
\hline
\end{tabular}

${ }^{1} \mathrm{n}=4$ per time and treatment combination.

${ }^{2} \mathrm{OSL}=$ Observed significance level for the preplanned contrasts.

${ }^{3}$ Time relative to administration of $25-\mathrm{OH} \mathrm{D}_{3}$. Sampling times -24 and $0 \mathrm{~h}$ were used as baseline covariates in the repeated measures analysis of 6 - and 24 -h data. The sampling time $\times$ treatment interaction was not significant $(P \geq 0.33)$ for samples collected at 6 and $24 \mathrm{~h}$.

${ }^{4}$ Pooled standard error of the treatment means for -24 - and 0 -h samples. Covariance-adjusted pooled standard errors for samples collected at 6 and $24 \mathrm{~h}$ were 15.6, 15.7, 16.2, and $15.5 \mathrm{pg} / \mathrm{mL}$ for the $0,10,100$, and $1000 \mathrm{mg}$ treatments, respectively. 
Table 3. Effects of buccal administration of 25-hydroxyvitamin $\mathrm{D}_{3}\left(25-\mathrm{OH}_{3}\right)$ on serum calcium concentration $(\mathrm{mg} / \mathrm{dL})$ in finishing beef heifers. ${ }^{1}$

\begin{tabular}{|c|c|c|c|c|c|c|c|c|}
\hline \multirow[b]{2}{*}{ Time ${ }^{3} \mathrm{~h}$} & \multicolumn{4}{|c|}{$25-\mathrm{OH} \mathrm{D}$ dose, $\mathrm{mg}$} & \multirow[b]{2}{*}{$\mathrm{SEM}^{4}$} & \multicolumn{3}{|c|}{$\mathrm{OSL}^{2}$} \\
\hline & 0 & 10 & 100 & 1000 & & 0 vs. 10 & 0 vs. 100 & Others vs. 1000 \\
\hline-24 & 10.6 & 10.4 & 10.3 & 10.8 & 0.143 & 0.34 & 0.16 & 0.02 \\
\hline 0 & 11.0 & 10.5 & 10.5 & 10.9 & 0.115 & 0.02 & 0.02 & 0.16 \\
\hline 6 & 10.5 & 10.7 & 11.0 & 11.0 & - & 0.62 & 0.24 & 0.46 \\
\hline 24 & 10.7 & 10.9 & 11.6 & 12.5 & - & 0.58 & 0.04 & 0.001 \\
\hline
\end{tabular}

${ }^{1} \mathrm{n}=4$ per time and treatment combinations.

${ }^{2} \mathrm{OSL}=$ Observed significance level for the preplanned contrasts.

${ }^{3}$ Time relative to administration of $25-\mathrm{OH} \mathrm{D}_{3}$. Sampling times -24 and $0 \mathrm{~h}$ were used as baseline covariates in the repeated measures analysis of 6 - and 24-h data. The sampling time $\times$ treatment interaction was significant $(P<0.003)$ for samples collected at 6 and $24 \mathrm{~h}$.

${ }^{4}$ Pooled standard error of the treatment means for -24- and 0-h samples. Covariance-adjusted pooled standard errors for samples collected at 6 and $24 \mathrm{~h}$ were $0.28,0.25,0.26$, and $0.27 \mathrm{mg} / \mathrm{dL}$ for the $0,10,100$, and $1000 \mathrm{mg}$ treatments, respectively.

trations of $25-\mathrm{OH} \mathrm{D}_{3}$ and $1,25-(\mathrm{OH})_{2} \mathrm{D}_{3}$ in cattle. Similarly, Okura et al. (2004) demonstrated effective absorption of $1,25-(\mathrm{OH})_{2} \mathrm{D}_{3}$ after vaginal administration in Holstein heifers. Heifers were given a single intravaginal dose of $1 \mu \mathrm{g}$ of $1,25-(\mathrm{OH})_{2} \mathrm{D}_{3} / \mathrm{kg}$ of $\mathrm{BW}$, and plasma concentrations of $1,25-(\mathrm{OH})_{2} \mathrm{D}_{3}$ increased significantly from the baseline concentration by $2 \mathrm{~h}$ and peaked $6 \mathrm{~h}$ after treatment. Taken with the present data, it seems that mucosal transfer of vitamin D metabolites $[25-\mathrm{OH}$ $\mathrm{D}_{3}$ and $1,25-(\mathrm{OH})_{2} \quad \mathrm{D}_{3}$ ] may be an effective means of rapidly increasing their concentrations in serum and plasma of beef and dairy cattle. Because of limitations in frequency of sampling, the current study does not provide conclusive proof of mucosal transfer after buccal administration of $25-\mathrm{OH} \mathrm{D}_{3}$. Some of the dose could have been swallowed by the animals, and with blood samples collected only at 6 and $24 \mathrm{~h}$ after dosing, it is not possible to distinguish between mucosal and gastrointestinal absorption. Moreover, it is possible that 10 $\mathrm{mL}$ of propylene glycol as a carrier for the $1000-\mathrm{mg}$ dose might have stimulated swallowing by heifers in that treatment group compared with the $1-\mathrm{mL}$ volume used in the other 3 groups. Thus, additional research is needed to determine whether increases in serum vitamin D metabolites as observed resulted solely from mucosal transfer of $25-\mathrm{OH} \mathrm{D}_{3}$ or from a combination of mucosal transfer and gastrointestinal absorption.

Administration of 100 and $1000 \mathrm{mg}$ of $25-\mathrm{OH} \mathrm{D}_{3}$ increased ( $P=0.04$ and 0.001 , respectively) serum Ca at $24 \mathrm{~h}$ after dosing (Table 3), but the 10-mg dose had little effect on serum Ca. These increases in serum $\mathrm{Ca}$ coincided with periods when $1,25-(\mathrm{OH})_{2} \mathrm{D}_{3}$ was increased by the 100- and 1000-mg doses (Table 2). Hodnett et al. (1992) reported similar increases in serum Ca following i.m. injection of cows with $0.5 \mathrm{mg}$ of 1- $\alpha(\mathrm{OH})_{2} \mathrm{D}_{3}$ and $4 \mathrm{mg}$ of $25-\mathrm{OH} \mathrm{D}_{3}$. Similarly, Hove et al. (1983) noted increases in Ca following i.m. and oral treatment with $500 \mu \mathrm{g}$ of $1,25-(\mathrm{OH})_{2} \mathrm{D}_{3}$.

No treatment $\times$ sampling time interactions were detected $(P \geq 0.14)$ for serum albumin, protein, $\mathrm{P}$, and $\mathrm{Mg}$, and main-effect means for samples collected 6 and $24 \mathrm{~h}$ after dosing are shown in Table 4 . Neither serum albumin nor protein differed $(P \geq 0.17)$ among treatments. Albumin is required to transport various serum constituents, and Yamaguchi et al. (2003) reported an increase in albumin in bone fractures of rats, which led to an increase in serum Ca. The results noted by Yamaguchi et al. (2003) were related to a need for bonestimulating factors associated with fractures, whereas the cattle in the current study had no such requirement. Serum $P$ concentration tended $(P=0.09)$ to be increased with the $1000-\mathrm{mg}$ dose of $25-\mathrm{OH} \mathrm{D}_{3}$ vs. the other treatments, but no differences $(P \geq 0.26)$ were observed among treatments for serum $\mathrm{Mg}$ concentrations (Table 4). Montgomery et al. (2004a) reported that feeding vitamin D at 1 and 5 million IU (/steer per d) for 8 $\mathrm{d}$ before slaughter increased serum $\mathrm{P}$ concentrations relative to controls, but Karges et al. (2001) reported no differences in serum $P$ following vitamin $D$ supplementation for 4 or $6 \mathrm{~d}$. In contrast to our results, however, Karges et al. (2001) noted a numerical decrease in serum Mg concentration following supplementation. Moreover, Hove et al. (1983) reported a decrease in $\mathrm{Mg}$ following treatment with vitamin D metabolites either orally or as an i.m. injection. That serum $\mathrm{Mg}$ failed to respond to increasing $25-\mathrm{OH} \mathrm{D}_{3}$ concentrations in the present study might reflect the duration of treatment. The cattle used by Karges et al. (2001) were administered the vitamin for 4 or $6 \mathrm{~d}$, whereas the cattle in our study were given $25-\mathrm{OH} \mathrm{D}_{3}$ only once. Similarly, Hove et al. (1983) sampled for a longer period than in our study. Levine et al. (1980) reported that serum Mg de- 
Table 4. Effects of buccal administration of 25-hydroxyvitamin $\mathrm{D}_{3}\left(25-\mathrm{OH} \mathrm{D}_{3}\right)$ on serum concentrations of albumin, protein, $\mathrm{P}$, and $\mathrm{Mg}$, and tissue concentrations of 1,25 dihydroxyvitamin $\mathrm{D}_{3}$ in finishing beef heifers.

\begin{tabular}{|c|c|c|c|c|c|c|c|c|}
\hline \multirow[b]{2}{*}{ Item } & \multicolumn{4}{|c|}{$25-\mathrm{OH} \mathrm{D}_{3}$ dose, $\mathrm{mg}$} & \multirow[b]{2}{*}{$\mathrm{SEM}^{2}$} & \multicolumn{3}{|c|}{$\mathrm{OSL}^{1}$} \\
\hline & 0 & 10 & 100 & 1000 & & 0 vs. 10 & 0 vs. 100 & Others vs. 1000 \\
\hline \multicolumn{9}{|l|}{ Serum $^{3}$} \\
\hline Albumin, g/dL & 3.9 & 3.9 & 4.0 & 3.9 & 0.04 & 0.89 & 0.17 & 0.80 \\
\hline Protein, g/dL & 7.6 & 7.6 & 7.7 & 7.6 & 0.08 & 0.94 & 0.29 & 0.70 \\
\hline $\mathrm{P}, \mathrm{mg} / \mathrm{dL}$ & 6.1 & 6.2 & 6.2 & 6.6 & 0.23 & 0.78 & 0.67 & 0.09 \\
\hline $\mathrm{Mg}, \mathrm{mg} / \mathrm{dL}$ & 2.1 & 2.2 & 2.1 & 2.1 & 0.05 & 0.50 & 0.91 & 0.26 \\
\hline \multicolumn{9}{|l|}{ Tissue, $\mathrm{pg} / \mathrm{g}$ of fresh tissue } \\
\hline Kidney & 239.9 & 247.2 & 289.4 & 436.3 & 40.2 & 0.09 & 0.40 & 0.002 \\
\hline Liver & 174.9 & 219.5 & 246.4 & 488.0 & 54.1 & 0.57 & 0.27 & 0.001 \\
\hline Longissimus lumborum & 30.8 & 32.5 & 98.4 & 99.6 & 13.0 & 0.92 & 0.003 & 0.01 \\
\hline Triceps brachii & 93.2 & 62.9 & 111.5 & 98.2 & 7.5 & 0.14 & 0.11 & 0.32 \\
\hline
\end{tabular}

${ }^{1} \mathrm{OSL}=$ Observed significance level for the preplanned contrasts.

${ }^{2}$ Pooled standard error of the treatment means; $n=8$ for serum variables, and $n=4$ for tissue concentrations. For serum data, the largest SE value among the 4 covariance-adjusted means is reported.

${ }^{3}$ No sampling time $\times$ treatment interactions $(P \geq 0.14)$ were observed for serum data collected 6 and 24 $\mathrm{h}$ after treatment. Samples collected 24 and $0 \mathrm{~h}$ before treatment were used as baseline covariates $(-24-$ and 6-h data not shown).

creased in vitamin D-deficient rats given injections of $1,25-(\mathrm{OH})_{2} \mathrm{D}_{3}$, but only after 5 to $8 \mathrm{~d}$ of treatment. Perhaps sampling for a longer period following administration with $25-\mathrm{OH} \mathrm{D}_{3}$ than was done in the present study might have increased the likelihood of detecting changes in serum Mg.

Compared with the other 3 treatments, $1000 \mathrm{mg}$ of buccally administered $25-\mathrm{OH} \mathrm{D}_{3}$ increased $(P \leq 0.01)$ concentrations of $1,25-(\mathrm{OH})_{2} \mathrm{D}_{3}$ in the kidneys, liver, and longissimus lumborum. Conversely, concentrations of $1,25-(\mathrm{OH})_{2} \mathrm{D}_{3}$ in triceps brachii muscle were not affected by any dose of $25-\mathrm{OH} \mathrm{D}_{3}(P \geq 0.11)$. The $100-\mathrm{mg}$ dose increased $(P=0.003)$ the concentration of 1,25 $(\mathrm{OH})_{2} \mathrm{D}_{3}$ in the longissimus sample, and the 10-mg dose tended $(P=0.09)$ to increase kidney concentrations of $1,25-(\mathrm{OH})_{2} \mathrm{D}_{3}$. Montgomery et al. (2000) reported increased $1,25-(\mathrm{OH})_{2} \mathrm{D}_{3}$ in top round steaks of cattle fed $7.5 \times 10^{6} \mathrm{IU} / \mathrm{d}$ for $9 \mathrm{~d}$ before slaughter, but observed no significant increases in concentrations of $1,25-(\mathrm{OH})_{2} \mathrm{D}_{3}$ in the kidneys, liver, or strip loin steaks. Similarly, Montgomery et al. (2004b) reported that liver, kidney, and longissimus muscle concentrations of $1,25-(\mathrm{OH})_{2}$ $\mathrm{D}_{3}$ in beef steers were generally not affected by feeding $0,0.5,1$, and 5 million IU (/steer per d) for $8 \mathrm{~d}$ before slaughter. Although more research is needed, it seems that feeding high doses of vitamin $\mathrm{D}_{3}$ might have different effects on tissue concentrations of $1,25-(\mathrm{OH})_{2} \mathrm{D}_{3}$ than buccal dosing of $25-\mathrm{OH} \mathrm{D} \mathrm{D}_{3}$.

Olson et al. (1974) conducted experiments to determine whether prolonged oral or injected $25-\mathrm{OH} \mathrm{D}_{3}$ would result in high vitamin $\mathrm{D}$ activity in milk and tissue, and concluded that doses of $25-\mathrm{OH} \mathrm{D}_{3}$ that would decrease the incidence of parturient paresis would not affect the safety of products from treated animals. The concentrations of $25-\mathrm{OH} \mathrm{D}_{3}$ in the longissimus and triceps samples in the present study were within range of the values observed by Olson et al. (1974).

Based on our results, buccal dosing seems to be a valid method to deliver $25-\mathrm{OH} \mathrm{D}_{3}$ to cattle. This method of dosing would allow for administration of the vitamin before slaughter or at other times when supplemental vitamin $\mathrm{D}$ is needed without causing injection site lesions at slaughter. Further research is needed to determine how long the concentrations of $25-\mathrm{OH} \mathrm{D}_{3}$ remain elevated following buccal administration, to determine whether similar results would be observed with other vitamins, and to compare blood and tissue concentrations in cattle dosed by the buccal route with more commonly used routes (e.g., i.m. injection, feeding).

\section{REFERENCES}

Belmin, J., and P. Valensi. 2003. Novel drug delivery systems for insulin: Clinical potential for use in the elderly. Drugs Aging 20:303-312.

Cefalu, W. T. 2002. Evaluation of alternative strategies for optimizing glycemia: Progress to date. Am. J. Med. 113. Suppl. 6A:23S-35S.

FASS. 1999. Guide for Care and Use of Agricultural Animal in Agricultural Research and Teaching. 1st rev. ed. Fed. Anim. Sci. Soc., Savoy, IL.

Hodnett, D. W., N. A. Jorgensen, and H. F. Deluca. 1992. $1 \alpha$-hydroxyvitamin $\mathrm{D}_{3}$ plus 25 -hydroxyvitamin $\mathrm{D}_{3}$ reduces parturient paresis in dairy cows fed high dietary calcium. J. Dairy Sci. 75:485-491.

Hove, K. R. L., R. L. Horst, and E. T. Littledike. 1983. Effects of $1 \alpha-$ hydroxyvitamin $\mathrm{D}_{3}, 1,25$-dihydroxyvitamin $\mathrm{D}_{3}, 1,24,25$-trihydroxyvitamin $\mathrm{D}_{3}$, and $1,25,26$ - trihydroxyvitamin $\mathrm{D}_{3}$ on mineral metabolism and 1,25-dihydroxyvitamin $\mathrm{D}$ concentrations in dairy cows. J. Dairy Sci. 66:59-66.

Karges, K., J. C. Brooks, D. R. Gill, J. E. Breazile, F. N. Owens, and J. B. Morgan. 2001. Effects of supplemental vitamin $D_{3}$ on feed intake, carcass characteristics, tenderness, and muscle properties of beef steers. J. Anim. Sci. 79:2844-2850. 
Levine, B. S., N. Brautbar, M. W. Walling, D. B. N. Lee, and J. W. Coburn. 1980. Effects of vitamin D and diet magnesium on magnesium metabolism. Am. J. Physiol. 239:515-523.

$\mathrm{Li}$, Y. C. 2003. Vitamin D regulation of the renin-angiotensin system. J. Cell. Biochem. 88:327-331.

Littledike, E. T., and R. L. Horst. 1982. Vitamin $\mathrm{D}_{3}$ toxicity in dairy cows. J. Dairy Sci. 65:749-759.

Montgomery, J. L., M. L. Galyean, R. L. Horst, K. J. Morrow, Jr., J. R. Blanton, Jr., D. B. Wester, and M. F. Miller. 2004a. Supplemental vitamin $\mathrm{D}_{3}$ concentration and biological type of beef steers. I. Feedlot performance and carcass traits. J. Anim. Sci. 82:2050 2058.

Montgomery, J. L., M. B. King, J. G. Gentry, A. R. Barham, B. L. Barham, G. G. Hilton, J. R. Blanton, Jr., R. L. Horst, M. L. Galyean, K. J. Morrow, Jr., D. B. Wester, and M. F. Miller. 2004b. Supplemental vitamin $\mathrm{D}_{3}$ concentration and biological type of steers. II. Tenderness, quality, and residues of beef. J. Anim. Sci. 82:2092-2104.

Montgomery, J. L., F. C. Parrish, Jr., D. C. Beitz, R. L. Horst, E. J. Huff-Lonergan, and A. H. Trenkle. 2000. The use of vitamin $\mathrm{D}_{3}$ to improve tenderness. J. Anim. Sci. 78:2615-2621.
NRC. 1987. Vitamin Tolerances of Animals. Pages 11-22. Natl. Acad. Press, Washington, DC.

Okura, N. N., M. Yamagishi, Y. Naito, K. Kanno, and M. Koiwa. 2004. Technical note: Vaginal absorption of $1,25(\mathrm{OH})_{2} \mathrm{D}_{3}$ in cattle. J. Dairy Sci. 87:2416-2419.

Olson, W. G., N. A. Jorgensen, A. N. Bringe, L. H. Schultz, and H. F. Deluca. 1974. 25-hydroxycholecalciferol (25-OH-D $)_{3}$. III. Effect of dosage on soft tissue integrity and vitamin $\mathrm{D}$ activity of tissues and milk from dairy cows. J. Dairy Sci. 57:677-682.

Reinhardt, T. A., and F. G. Hustmyer. 1987. Role of vitamin D in the immune system. J. Dairy Sci. 70:952-962.

Rivera, J. D., G. C. Duff, M. L. Galyean, D. M. Hallford, and T. T. Ross. 2003. Effects of graded levels of vitamin $\mathrm{E}$ on inflammatory response and evaluation of methods of supplementing vitamin $\mathrm{E}$ on performance and health of beef steers. Prof. Anim. Sci. 19:171-177.

Roeber, D. L., R. C. Cannell, W. R. Wailes, K. E. Belk, J. A. Scanga, J. N. Sofos, G. L. Cowman, and G. C. Smith. 2002. Frequencies of injection-site lesions in muscles from rounds of dairy and beef cow carcasses. J. Dairy Sci. 85:532-536.

Yamaguchi, M., A. Igarashi, H. Misawa, and Y. Tsurusaki. 2003. Enhancement of albumin expression in bone tissues with healing rat fractures. J. Cell. Biochem. 89:356-363. 